\title{
Työelämään yhdistetty vuorovaikutuskoulutus farmasiassa
}

Marja-Leena Hyvärinen

Lectio praecursoria puheviestinnän väitöskirjaksi tarkoitetun tutkimuksen Alakohtainen vuorovaikutuskoulutus farmasiassa tarkastustilaisuudessa Tampereen yliopistossa 6.5.2011. Vastaväittäjänä toimi dosentti Eeva Pyörälä (Helsingin yliopisto) ja kustoksena professori Pekka Isotalus.

Eri alojen asiantuntijatehtävissä ja ammateissa työtä tehdään vuorovaikutuksessa erilaisten ihmisten kanssa. Sen vuoksi ammattilainen tarvitsee oman alansa tietojen ja taitojen lisäksi vuorovaikutustaitoja ja ymmärrystä viestinnän vaikutuksesta työn tuloksiin. Esimerkiksi apteekissa farmaseutin ja asiakkaan välisen vuorovaikutuksen onnistumisella on merkittävä yhteys asiakkaan ongelman ratkaisuun, oikean hoidon valintaan, hoito-ohjeiden noudattamiseen, lääkkeistä aiheutuvien haittojen ehkäisemiseen ja hoidon seurantaan. Tällaisiin työtehtäviin kouluttautuvan opiskelijan tulisi voida yhdistää sekä ammatillisten tietojen että vuorovaikutustaitojen opiskelu.

Yliopistotutkintojen kieli- ja viestintäopintoihin sisältyvää vuorovaikutuskoulutusta annetaan yleensä opintojen alkuvaiheessa erillisinä puheviestinnän kursseina. Julkisen esiintymisen taitoja opetetaan yhä edelleen riippumatta opiskelijan oman alan tai työelämän tarpeista. Entuudestaan tiedetään, että opiskelijat ovat tyytyväisiä puheviestinnän opetukseen, mutta he eivät välttämättä koe hyötyneensä siitä työelämän tarpeiden kannalta riittävästi. Lisäksi opintojen suorittamista erillisinä kursseina ja usein tutkinnon alkuvaiheessa on pidetty ongelmallisena opiskelijan tulevassa ammatissa tarpeellisen vuorovaikutusosaamisen oppimiseksi. Tästä syystä on kehitetty opetusta, jossa opiskelija voi yhdistää oman alansa tietojen ja vuorovaikutustaitojen opiskelun ja joka ottaa huomioon alakohtaiset ja ammatilliset erityisvaatimukset ja ominaisuudet.

Pelkkä puheviestinnän opetuksen yhdistäminen opiskelijan tutkintoon ei kuitenkaan yksin riitä takaamaan alakohtaisuuden tai ammatillisten erityisvaatimusten toteutumista. Useat tutkijat ovat huolissaan siitä, että puheviestinnän alalta puuttuu teoreettiseen tietoon perustuva ymmärrys viestinnän alasidonnaisesta luonteesta. Lisäksi puuttuu riittävän vahvat ja uskottavat perustelut, miksi alakohtaista puheviestinnän opetusta ylipäätään tarvitaan ja miten tietylle alalle tai tiettyyn ammattiin valmistuvalle opiskelijalle suunnattua koulutusta voidaan toteuttaa, arvioida ja kehittää. 
Väitöskirjatutkimuksessani halusin selvittää, miten farmaseuttiopiskelijoiden puheviestinnän opetusta ja oppimisen arviointia voidaan toteuttaa mahdollisimman kiinteässä yhteydessä opiskelijan tulevaan ammattiin ja työelämään. Uutta oli opiskelijan työharjoittelujakson ja ammatissa toimivien työntekijöiden antaman ohjauksen hyödyntäminen vuorovaikutuskoulutuksessa. Tutkimuksen lähestymistapaa, menetelmiä ja tuloksia voidaan soveltaa vuorovaikutuskoulutuksen tutkimiseen ja kehittämiseen esimerkiksi lääketieteessä, ravitsemustieteessä ja sosiaalitieteissä.

Teoreettisesti tutkimus perustui alakohtaiseen viestintäpedagogiikkaan, jonka mukaan asiantuntijuus kehittyy vähitellen tilanteissa, joissa yksilö osallistuu alansa asiantuntijayhteisöjen toimintaan, esimerkiksi työpaikoilla. Silloin kun esimerkiksi opiskelija osallistuu työharjoittelujaksolla erilaisiin vuorovaikutustilanteisiin työpaikallaan, hän samalla kasvaa työyhteisönsä jäseneksi ja oppii niitä käytänteitä, joita kyseinen ala itse pitää hyödyllisinä ja toimivina. Teorian mukaan kukin ala itse määrittelee, mitkä vuorovaikutustilanteet ovat alalla keskeisiä, millaista osaamista niissä tarvitaan ja millaista viestintäkäyttäytymistä pidetään tilanteeseen ja tarkoitukseen sopivana. Ymmärrys alalla vaadittavasta osaamisesta muovautuu ihmisten välisessä yhteistoiminnassa. Tästä syystä vuorovaikutuskoulutuksen tulisi tiiviisti liittyä alan omiin toimintakäytänteisiin ja niihin tilanteisiin, joissa opittua todellisuudessa käytetään.

Havainnollistan asiaa esimerkin avulla. Kun opiskelija osallistuu opintojensa aikana tietyn oppiaineen opetukseen ja oppimisyhteisön toimintaan, hän samalla oppii kyseiselle oppiaineelle ja yhteisölle ominaisia käytänteitä, arvoja ja toimintaa ohjaavia normeja. Vastaavasti, kun opiskelija siirtyy jonkin toisen oppiaineen opetukseen, hän pyrkii oppimaan tälle oppiaineelle ominaiset toimintatavat. Tämän vuoksi, vaikka opetuksessa pyrittäisiin luomaan mahdollisimman kiinteä yhteys ammatilliseen tilanteeseen ja aitoihin työelämän käytänteisiin, on hyvin todennäköistä, että opiskelija oppii sellaisia toimintatapoja, joita kyseinen oppiaine arvostaa. Näin ollen esimerkiksi puheviestinnän kurssilla opittu ei välttämättä vastaa niitä odotuksia ja tarpeita, joita työelämässä on, ja toisin päin, työelämä ei tue puheviestinnän kurssilla opitun soveltamista työtehtäviin.

Tämäntyyppistä lähestymistapaa voidaan kuitenkin perustellusti myös väittää ongelmalliseksi. Se voi ohjata esimerkiksi ajattelemaan, että puheviestinnän opetus on pelkkää neutraalia tai reagoivaa toimintaa suhteessa työelämään. Otin tämän näkökulman huomioon ja pyrin tässä tutkimuksessa etsimään vastausta myös siihen, miten vuorovaikutuskoulutus voisi olla kehittämässä työkulttuuria ja uudenlaisia toimintakäytänteitä työpaikoille.

Mielestäni ammatillisesti suuntautuneen vuorovaikutuskoulutuksen yksi keskeinen haaste on juuri siinä, miten opiskelija saadaan siirtämään puheviestinnän kurssilla oppimaansa työelämään ja kehittämään osaamistaan yhä edelleen sekä itsenäisesti että yhteistyössä muiden alansa ammattilaisten kanssa. 
Tämän vuoksi on tärkeää, että opiskelija voi harjoitella aidoissa työtilanteissa, arvioida itse omaa oppimistaan ja saada palautetta työntekijöiltä. Oman toiminnan tarkasteleminen eri näkökulmista ja palautekeskustelu voivat edistää vuorovaikutusta opiskelijan ja ammattihenkilöstön välillä. Samalla voidaan auttaa muodollisessa koulutuksessa opitun siirtämistä työhön ja työyhteisön toimintakulttuuriin. Kysymys on molemminpuolisesta oppimisesta, jossa sekä opiskelija että työntekijä oppivat toinen toisiltaan.

Tähän mennessä alakohtaista vuorovaikutuskoulutusta on tutkittu lähinnä yliopistoissa ja se on keskittynyt esiintymistaitoihin. Tutkimusta on tehty muun muassa teknisillä aloilla, arkeologiassa, lääketieteessä sekä arkkitehtuurin, muotoilualan ja ravitsemusneuvonnan parissa. Sen sijaan vähemmän on tutkittu, miten ammatillisesti suunnattua vuorovaikutuskoulutusta voidaan yhdistää aitoihin työtilanteisiin. Myös tietyn alan asiantuntijatehtävässä tai ammatissa tarpeellisen vuorovaikutusosaamisen opetus- ja arviointimenetelmien tutkimus on ollut toistaiseksi vähäistä. Farmaseuttien alakohtaista vuorovaikutuskoulutusta ei ole aiemmin juurikaan tutkittu.

Tämä tutkimus koostui neljästä osatutkimuksesta, joissa tarkastelin farmaseuttiopiskelijoiden käsityksiä apteekin asiakaspalvelutyössä tarvittavasta vuorovaikutusosaamisesta ja oppimisesta, aidoissa asiakaspalvelutilanteissa tapahtuvaa harjoittelemista sekä harjoituksiin kehitettyä opetus- ja arviointimenetelmää. Harjoitusten keskeinen idea oli toiminta aidossa asiakaspalvelutilanteessa, minkä jälkeen opiskelija sai palautetta tilannetta seuranneelta farmaseutilta tai proviisorilta harjoitusten tueksi laadittujen palautekysymysten avulla. Tavoitteena oli selvittää, miten yliopistossa kehitetty opetusmenetelmä soveltuu ammatillisen vuorovaikutusosaamisen kehittämisen välineeksi työelämässä, miten menetelmää sovelletaan käytäntöön ja miten menetelmän käyttö vaikuttaa sekä opiskelijan että ohjaajan oppimiseen.

Tutkimusaineistot kerättiin farmaseuttiopiskelijoilta, heidän työharjoitteluaan ohjanneilta farmaseuteilta ja proviisoreilta sekä farmasian ja puheviestinnän opettajilta Kuopion yliopiston (nykyisin Itä-Suomen yliopisto) farmaseuttiopiskelijoiden vuorovaikutuskoulutuksen yhteydessä vuosina 2004-2007. Kaikkiaan aineistoja kerättiin neljältä eri opiskelijaryhmältä ja heidän ohjaajiltaan sekä kahdelta farmasian ja kahdelta puheviestinnän opettajalta. Tutkimukseen osallistuneita opiskelijoita oli yhteensä 519 ja ohjaajia 217.

Tutkimuksessa käytettiin sekä laadullisia että määrällisiä tutkimusmenetelmiä. Tutkimusaineistoina käytettiin opiskelijoiden kirjoitelmia sekä kyselyitä opiskelijoille ja heidän ohjaajilleen ensimmäisen työharjoittelujakson päätteeksi. Lisäksi aineistoa kerättiin yliopistossa vuorovaikutuskoulutuksen päätteeksi pidetyistä asiakasneuvonnan näyttökokeista. Seuraavaksi nostan esille muutamia tutkimukseni keskeisimpiä tuloksia, joita voidaan pitää rohkaisevina ammatillisesti suuntautuneen ja työelämään yhdistetyn vuorovaikutuskoulutuk- 
sen kehittämiseksi. Rajaan tarkastelun tässä tutkimuksessa kehitettyihin opetusja arviointimenetelmiin sekä molemminpuolisen oppimisen näkökulmaan.

Tulosten perusteella ammatillisesti suunnattu vuorovaikutuskoulutus voi olla rakentamassa uusia toimintakäytänteitä ja uudenlaista työkulttuuria työpaikoille. Aitoihin työtilanteisiin yhdistettyjen harjoitusten ja palautekeskusteluiden avulla farmaseuttiopiskelija ja hänen ohjaajansa yhdessä rakentavat näkemystä alansa asiantuntijuudesta ja osaamisvaatimuksista. Opiskelijoiden mielestä farmaseutin työssä keskeistä on toimia asiakas- ja tilannekohtaisesti ja saada asiakas mukaan terveyteensä tai sairautensa hoitoon liittyvään keskusteluun ja päätöksentekoon.

Tutkimuksessa kehitetyt opetus- ja arviointimenetelmät osoittautuivat toimiviksi. Ne auttoivat jäsentämään ammatin kannalta keskeisiä vuorovaikutustaitoja, havainnoimaan ja erittelemään viestintää sekä antamaan oppimista edistävää palautetta opiskelijalle. Opiskelijat tarvitsevat rakentavaa palautetta itsetuntemuksensa lisäämiseen ja vuorovaikutusosaamisensa itsearviointiin. Alakohtaisille arviointikriteereille on tarvetta ja niitä tulee käyttää koko oppimisprosessin ajan.

Myös työntekijät oppivat ohjatessaan opiskelijoiden harjoituksia. Harjoitusten ohjaaminen ja opetusmenetelmän käyttö auttoivat heitä jäsentämään ammatillista vuorovaikutusosaamista ja pohtimaan viestintäkäyttäytymistä. Lisäksi ohjaajat oppivat ymmärtämään, miksi vuorovaikutusosaaminen on tarpeellista, mikä yhteys sillä on työn tuloksiin, miten vuorovaikutusosaamista voidaan kehittää ja mikä merkitys palautteella on kehittymiseen. Tutkimuksessa havaittu molemminpuolinen oppiminen on uusi näkökulma, jota tulee alakohtaisessa viestintäpedagogiikassa jatkossa korostaa.

Ohjaajien rooli on keskeinen työelämään liitetyssä vuorovaikutuskoulutuksessa. Pelkkä ammatissa toimiminen ei kuitenkaan kehitä riittävästi ohjaamiseen tarvittavaa osaamista. Ohjaajat tarvitsevat koulutusta erityisesti vuorovaikutuksen havainnoinnissa, erittelemisessä ja oppimista edistävän palautteen antamisessa. Jokseenkin huolestuttavana voidaan pitää tulosta, jonka mukaan ainoastaan kolmannes opiskelijoista raportoi olevansa tyytyväinen saamansa palautteen laatuun. Yksi tutkimuksen keskeisistä havainnoista kertoo, että työpaikan omilla käytänteillä ja toimintakulttuurilla on merkittävä vaikutus siihen, millaisia oppimiskokemuksia opiskelijat saavat. Harjoitukset ja palautekeskustelut onnistuivat paremmin niissä apteekeissa, joissa oli sisäisiä sopimuksia asiakasneuvonnasta, yhdessä jaettu näkemys toimintatavoista, riittävät voimavarat opiskelijoiden ohjaamiseen sekä koulutetut, työharjoittelujakson tavoitteisiin ja tehtäviin perehtyneet ohjaajat.

Koska työelämässä toimivien ammattilaisten toimintakäytänteiden muuttaminen on ilmeisen vaativa tehtävä, asettuu perusopiskelijoiden kouluttaminen entistä tärkeämpään asemaan alakohtaisten käytänteiden kehittämiseksi. Tästä syystä on jopa välttämätöntä, että vuorovaikutuskoulutuksessa tietoisesti 
tuetaan opiskelijoiden yleisten työelämävalmiuksien kehittämistä. Ammattiin valmistuvan opiskelijan tulisi pystyä soveltamaan omaa osaamistaan erilaisiin työelämän viestintätilanteisiin monipuolisesti ja laaja-alaisesti. Esimerkiksi asiakasneuvonnassa tarpeelliset vuorovaikutustaidot ja palautekeskustelutaidot ovat sellaista osaamista, jota voidaan, ja jota tulisi osata soveltaa, myös muihin työyhteisön tilanteisiin.

Palautteen merkitystä ei tämän tutkimuksen perusteella voida väheksyä. Harjoitteleminen joko todellisuutta jäljittelevässä tai aidossa työtilanteessa ja palaute tukevat vuorovaikutusosaamisen oppimista parhaiten. Vaikka opiskelijat itse olettivat olevansa liian kriittisiä itseään kohtaan, tulokset osoittavat, että todellisuudessa opiskelijoilla on taipumusta yliarvioida omaa osaamistaan. Tämän vuoksi on tärkeää, että opiskelijoita ohjataan tekemään riittävän kriittistä ja todenmukaista itsearviointia.

Yksi vuorovaikutuskoulutuksen kehittämisen keskeisistä haasteista on oppimista ja reflektiivistä toimintaa edistävän arvioinnin toteuttaminen. Tuloksissa korostui opiskelijoiden tarve saada täsmällistä palautetietoa vuorovaikutusosaamisestaan ja toisaalta tuli esille, että ohjaajilla oli vaikeuksia seurata asiakasneuvontatilanteita, antaa palautetta ja ylipäätään hahmottaa, millaista vuorovaikutusosaamista ollaan oppimassa. Juuri näistä syistä päädyin tämän tutkimusprosessin edetessä testaamaan opiskelijoiden näyttökokeisiin laadittuja arviointikriteereitä ja arvioimaan, miten hyvin ne soveltuisivat asiakasneuvonnan harjoitusten itsearviointiin ja palautekeskusteluihin. Tutkimuksessa testatut arviointikriteerit osoittautuivat luotettavaksi ja niiden systemaattinen käyttö näyttäisi ohjaavan yhdenmukaiseen arviointiin. Tältä osin tutkimuksessa saatiin hyvä pohja jatkotutkimukselle, jossa tulisi testata esimerkiksi sitä, auttaisivatko yksityiskohtaiset osaamiskuvaukset myös työharjoittelun ohjaajia käymään palautekeskustelua ja arviomaan opiskelijan toimintaa asiakaspalvelutyössä.

Yhteenvetona voidaan todeta, että alakohtainen viestintäpedagogiikka tarjosi mielekkään kehyksen tutkimuskohteen tarkasteluun. Kokonaisuutena tutkimus antoi arvokasta näkökulmaa farmaseutin työhön, aitoihin työtilanteisiin yhdistettyyn vuorovaikutuskoulutukseen sekä alakohtaisten opetus- ja arviointimenetelmien kehittämiseen. Tutkimuksessa saatiin moniulotteista kuvaa alakohtaisen viestintäpedagogiikan käytäntöön soveltamisesta opiskelijoiden, työharjoittelun ohjaajien sekä farmasian ja puheviestinnän opettajien arvioimana. Lisäksi tutkimuksessa kehitettiin alakohtaista viestintäpedagogiikkaa yhdistämällä vuorovaikutuskoulutusta työelämään ja ulottamalla koulutuksen vaikutus koko työyhteisön toimintakulttuurin ja työkäytänteiden kehittämiseen. 